Годищњак Филозофског̄ факулиеиейа у Новом Саду, Къиг̄a ХХХVIII (2013)

Annual Review of the Faculty of Philosophy, Novi Sad, Volume XXXVIII (2013)

Ана Халас

Филозофски факултет

Универзитета у Новом Саду

УДК: 81’373/374:811.163.41’373.42

Оригинални научни рад

\title{
ОБРАДА ВИШЕЗНАЧНОГ ГЛАГОЛА ГЛЕДАТИ \\ У ШЕСТОТОМНОМ И ЈЕДНОТОМНОМ РЕЧНИКУ МАТИЦЕ СРПСКЕ
}

У овом раду разматрају се примењене лексикографске стратегије при обради вишезначних лексема у вишетомном и једнотомном Речнику Матице српске. Обрада полисемије се анализира кроз три аспекта лексикографске праксе: идентификацију и диференцијацију значења, структуру и организацију речничког чланка и илустрацију контекста у којем се посматрана значења јављају. Анализирана је одредница глагола г̇ледайи одабраног због своје богате полисемантичке структуре засноване на деловању различитих механизама деривације значења. Циљ овог истраживања јесте утврђивање предности и недостатака система обраде полисемије у посматраним речницима, као и сличности и разлика између два система с обзиром да постоји известан временски јаз између вишетомног и једнотомног издања речника, те се може проверити потенцијални напредак и осавремењивање лексикографске праксе. Резултати анализе омогућавају селекцију лексикографских стратегија које су у складу са лексиколошком теоријом, али и ефикасне у смислу прегледног и систематичног представљања полисемантичке структуре у оквиру речничког чланка, што се може и илустровати формирањем предлога за одредницу посматраног глагола.

Кључне речи: лексикологија, лексикографија, прототип, полисемија

\section{1. УВОД}

Овај рад се бави једним од најкрупнијих лексикографских проблема при састављању речника - обрадом вишезначних лексема. Поменути својеврсни лексикографски изазов може се у најгрубљим цртама свести на идентификацију и рашчлањење значењске структуре вишезначне лексеме и њено прегледно представљање у оквиру речничког чланка у виду листе нумерисаних и јасно диференцираних главних значења са својим подзначењима како би сложена семантичка структура дате лексеме била лако доступна и разумљива корисницима речника. Уколико се дата сложена полисемантичка структура лексеме на одговарајући начин и устроји, корисницима је омогућено једноставно проналажење траженог значења, али и стицање увида у његов

*anahalas@gmail.com

Овај рад написан је у оквиру пројекта бр. 178002 под називом Језици и кулйуре у времену и йроcйору, који финансира Министарство за науку и технолошки развој Републике Србије. 
однос према осталим значењима у структури, а посебно у однос према примарном значењу.

Предмет овог рада обухвата анализу обраде полисемије у српској лексикографској пракси, чији су, свакако, најистакнутији представници шестотомни и једнотомни Речник Матице српске, и то на примеру одреднице глагола глледайи. Лексикографска пракса обраде вишезначних лексема разложена је у овом раду на три аспекта: идентификацију и диференцијацију значења, структуру и организацију речничког чланка и илустрацију контекста у којима се дата значења испољавају. Поменути аспекти истовремено представљају и критеријуме за анализу, која подразумева и поређење лексикографске праксе у двама речницима. Циљ овакве анализе јесте утврђивање сличности и разлика између старијег шестотомног и новијег једнотомног издања речника у погледу наведених критеријума, као и степен усклађености примењених стратегија са захтевима систематичне, доследне, прегледне и презицне лексикографске праксе при обради вишезначних лексема утемељене на лексиколошким теоријским достигнућима.

Резултати анализе пружају основу за извођење закључака о томе који поступци припадају адекватној лексикографској обради полисемије, а чија се примена може илустровати формирањем одреднице посматраног глагола према наведеним закључцима.

\section{2. ПОЛИСЕМИЈА У ЛЕКСИКОЛОШКОЈ ТЕОРИЈИ}

Даринка Гортан-Премк (2004: 38), једна од најзначајнијих ауторки србистичке лексиколошке литературе, када је реч о полисемији, нуди дефиницију према којој је полисемија способност лексеме да се реализује у више значења, која чине њену полисемантичку структуру. Поменута ауторка узроке полисемије види у богатству основног семантичког садржаја, чији су елементи извор асоцијација на основу којих се изводе нова значења лексеме, која се реализују њеном употребом у специфичном контексту (Гортан-Премк 2004: 42).

Рајна Драгићевић (2007: 129), пак, сматра да је термин полисемија сам по себи двозначан, јер може означавати како способност лексеме да има више значења, тако и механизме путем којих се нова значења развијају од основног или примарног, међу којима се посебно истичу метафора и метонимија. Ипак, проминентна одлика полисемије, коју истиче Алан Круз (2004: 108), јесте мотивисана међусобна повезаност свих значења која чине полисемантичку структуру једне лексеме, што је сасвим логичан закључак уколико се за полазиште узме претпоставка да се сва значења изводе од основног деловањем различитих механизама полисемије. Дакле, у покушају формулисања свеобухватне дефиниције полисемије може се тврдити да она подразумева способност лексеме да се реализује у више значења од којих су сва међусобно повезана у оквиру исте значењске структуре, а уколико се жели проговорити и о лексикографском аспекту, потребно је нагласити да се сва значења једне лексеме представљају у оквиру истог речничког чланка. 
У овом раду појам полисемије тумачи се кроз призму когнитивног приступа значењу лексема. Управо је овај приступ тај који у први план истиче међусобну повезаност значења једне лексеме. Наиме, у оквиру когнитивног приступа, семантичка структура је представљена према теоријском моделу прототипа, док се за њену визуелну представу користи радијални дијаграм. Како тврде Еванс и Грин (2006: 331), семантичка структура лексеме јесте појмовна категорија, где се свако значење схвата као посебан члан категорије од којих су сви повезани најпре са централним чланом категорије, прототипом, што је у семантичкој структури основно или примарно значење, а потом и међусобно. Наведена тврдња јасно указује на једну од карактеристика теорије прототипа, коју истиче Херартс (1989), а то је да сви чланови једне категорије нису њени подједнако репрезентативни представници, што имплицира да су неки чланови типичнији представници од других, док је у средишту категорије њен најтипичнији члан, прототип. Стога, у свакој категорији, па и значењској структури, постоји централни члан, прототип, тј. основно значење и периферни чланови, секундарна значења изведена од основног. Значења једне лексеме, дакле, заузимају своју позицију у оквиру полисемантичке структуре на основу степена своје блискости са прототипским значењем. Још једна од карактеристика модела прототипа јесте да границе између категорија нису увек јасно одређене. Тако, често је тешко јасно и прецизно диференцирати значења лексеме.

Према теорији прототипа примењеној на категорију значења, полисемантичка структура представља групу значења у чијем се центру налази основно или примарно значење око кога су окупљена секундарна, односно периферна значења, а њихова повезаност са заједничким центром од кога су изведена чини их међусобно повезаним, што указује на то да је полисемантичка структура устројена по принципу породичне сличности, што се визуелно најподесније представља радијалним скупом повезаних значења, која се могу и међусобно преклапати.

Бругман и Лејкоф описују модел радијалног дијаграма као начин визуелног представљања семантичке структуре на следећи начин: централни члан представља когнитивни модел од кога се мотивисано изводе остала периферна значења, која су радијално груписана око центра и са њим повезана путем механизама полисемије (цитирано у Левандовска-Томашчик, 2007: 148). Другим речима, међу члановима структуре постоје везе које показују како се значења развијају једно из другог, што показује и радијални дијаграм:

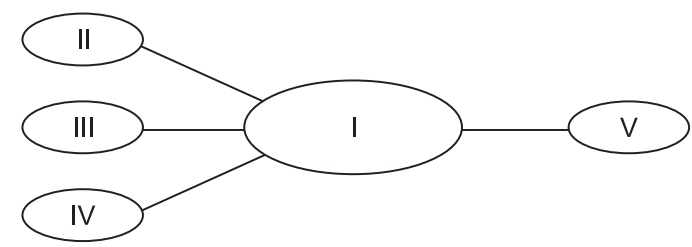

Слика 1: Модел радијалног дијаграма који нуди Левандовска-Томашчик (2007: 156) 


\section{3. ПОЛИСЕМИЈА У ЛЕКСИКОГРАФСКОЈ ПРАКСИ}

Говорећи о проблему лексикографских стратегија при обради вишезначних лексема, значајно је поменути Згустино запажање (1971: 64) према коме се сваки лексикограф, анализирајући богату полисемантичку структуру лексеме, неминовно сусреће са чињеницом да дата значења заправо чине мрежу у којој се многа од њих међусобно преклапају, те постоји приличан број граничних случајева. У тим случајевима могућа су два приступа: диференцијација на неколико засебних значења или, пак, груписање у једно значење са могућим подзначењима. Одабир једног од два приступа јесте саставни део најважнијег и најизазовнијег задатка лексикографа при обради полисемије, а то је идентификација и диференцијација појединачних значења вишезначних лексема и њихово представљање у оквиру речничког чланка. Овај задатак је додатно отежан и чињеницом да је значење речи, према тврдњи Килгарифа (2006: 29), субјективан појам, те да постоје различита тумачења о томе колики је опсег појединачног значења и како одредити границу која ће одвојити два сродна значења.

Стога, неопходно је утврдити поуздану методологију која ће се састојати од лексикографских стратегија за диференцијацију значења и то користећи индикаторе значења који се препознају на основу контекста у коме се посматрана лексема јавља, као што су: лексичко-граматичке одлике лексеме, колокацијски спојеви, специфичност референта, метафорички и метонимијски пренос значења и др.

Идентификација и диференцијација појединачних значења лексеме заправо се своди на одређивање дубине анализе и разлагања семантичке структуре лексеме на појединачна значења. То значи да лексикограф може представити семантичку структуру лексеме разлажући је само до нивоа најистакнутијих, односно најфреквентнијих значења или, пак, може заћи у дубљу анализу разлажући дату структуру до нивоа истанчанијих нијанси значења, при чему се долази до већег броја диференцираних значења. Одабрани приступ може бити условљен, свакако, типом речника.

Поменути задатак се може дефинисати и као одабир једне од две лексикографске методе - спајање или раздвајање значења. Прва метода подразумева спајање финијих значењских нијанси у једно значење тако да су све нијансе обухваћене уопштавањем дефиниције јединственог значења. Друга метода стоји насупрот првој односећи се на разлагање значењске структуре на финије нијансе од којих се свака третира као засебно значење. У овом другом случају, неопходно је јасно одредити границу до које се разлажу значења, јер постоји опасност од извођења превише детаљне полисемантичке структуре са већим бројем појединачних значења, што знатно отежава даље структурирање и организацију прегледног речничког чланка са јасно дефинисаним и нумерисаним значењима укључујући и илустрацију контекста у којем се јављају. 
Након идентификације и диференцијације свих значења једне лексеме, неизоставно се намеће одређивање примарног или основног значења и његово адекватно постављање у оквиру листе значења као следећи корак у сложеном лексикографском послу. Принципи одређивања примарног значења могу бити различити, попут оних које сугерише Алан Круз (2004:195), а то су историјски, при чему се као примарно значење даје оно које је прво забележено у језичкој употреби, или, пак, принцип фреквентности према коме се најфреквентније значење у језичкој употреби сматра примарним. Примарним значењем се може сматрати и оно које говорници одређеног језика прво имају на уму при сусрету са одређеном лексемом, које се према Згусти може назвати и доминантним значењем. Уколико се за теоријско полазиште узме когнитивни приступ и теорија прототипа, примарно значење се одређује као семантичка основа од кога су се развила остала периферна значења и то деловањем неког од механизама полисемије.

Након установљења полисемантичке структуре лексеме следи њена организација и представљање у оквиру речничког чланка. Према когнитивном приступу, семантичка структура лексеме јесте мултидимензионална структура ${ }^{1}$, услед чега настаје проблем при организацији и представљању такве структуре у оквиру речничког чланка, који Херартс (2001: 13) назива проблемом линеаризације, а који поставља питање пресликавања мултидимензионалне структуре на линеарно организован речнички чланак. Како би решили овај проблем, лексикографи прибегавају некој од стратегија као што су специфично означавање, груписање значења, успостављање хијерархијске структуре итд.

На основу изнесених и описаних кључних корака при обради вишезначних лексема, јасно је да овај лексикографски изазов представља сложен процес састављен од неколико фаза, при чему је неопходна примена одговарајућих лексикографских стратегија како би се постигло верно одсликавање дате семантичке структуре нумерисаном листом значења у речничком чланку.

\section{4. АНАЛИЗА}

Истакнути представници српске лексикографске праксе су, свакако, Речник српскохрватског књижевног језика Матице српске шестотомни и Речник српског језика Матице српске једнотомни, који су стога и подесни као извор одредница за дату анализу. Први речник је настао као једнојезични речник савременог књижевног језика средњег обима са фондом који чини приближно 150.000 речи. Томови овог речника објављивани су од 1967. до 1976. године. Током 2007. године објављен је једнотомни Речник српског језика Матице српске који обухвата око 80.000 речи стандардног српског језика.

Како је већ наглашено, према принципима когнитивне лингвистичке теорије, семантичка структура се развија од центра у коме се налази основно значење око кога су окупљена периферна значења, а која опет могу представљати полазиште за даље извођење нових значења. 
С обзиром на временски јаз између шестотомног и једнотомног издања, одреднице ова два речника погодне су за поређење у погледу сличности и разлика у примењеним лексикографским стратегијама при формирању одредница, тј. у смислу промене и потенцијалног напретка у лексикографској пракси.

Предмет анализе је одредница глагола глледай $и$, који пружа богату полисемантичку структуру, не само у смислу броја значења и подзначења, већ и разноврсности механизама чијим деловањем су значења и настала, што за собом повлачи и успостављање различитих критеријума за идентификацију и диференцијацију појединачних значења на основу којих се анализом може стећи увид у примењене лексикографске стратегије. Аспекте лексикографске праксе је најподесније анализирати на примеру богате мреже значења, јер она као таква представља изазов у погледу јасног, прегледног и доследног одсликавања вишезначности.

Поменута одредница анализирана је у оба речника на основу следећа три критеријума: 1. идентификација и диференцијација значења, 2. структура и организација речничког чланка и 3 . илустрација контекста у којем се идентификована значења јављају. Две лексикографске обраде наведене лексеме се затим пореде на основу резултата анализе посматраних аспеката лексикографске праксе у смислу изналажења сличности и разлика, предности и недостатака.

4.1 Идентификација и диференцијација значења

4.1.1 Идентификација примарног значења

Примарно значење глагола геледайи утврђено као семантичка основа без додатних конотација и фигуративног преноса значења, односно прототипско значење овог глагола, те као полазиште за даље извођење значења подразумева перцепцију чулом вида која не припада вољним радњама субјекта. Међутим, прво излистано значење у речничком чланку шестотомног речника, што је очекивано позиционирање основног значења, а које је заправо подељено на три подзначења, не садржи назначену примарну семантичку компоненту како се и види у издвојеном делу анализираног чланка:

гледати, -а̄м несврш. 1. а. имайи йог̄лед, очи уйрављене на неког̄а или на

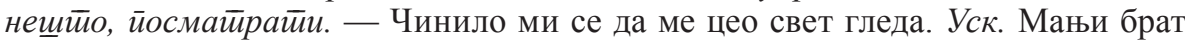
почео натуцати слова гледајући преко братова рамена у читанку. Гор. фиг. Из

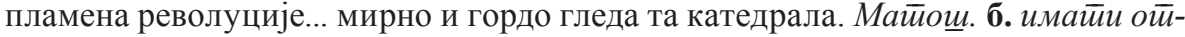
ворене очи; супр. жмурити. в. покр. видетии (неког̄a). — Виђао сам га... у граду. Но поодавно га не гледах. Кости. Л. Гледа [свет] нечувен призор, какав се никада није ту гледао. Дом.

Уколико се за теоријско полазиште узме когнитивни семантички приступ, односно теорија прототипа према којој се семантичка мрежа шири од центра ка периферији, значење излистано као примарно у датом речнику не може представљати и основно значење, јер је, заправо, изведено од претходно дефинисане семантичке основе изменом једне компоненте значења, и то 
у овом случају [-вољна радња] у њену супротност, односно присуство дате особине, [+вољна радња]. Остала два значења понуђена у оквиру одељка примарног значења, такође, не могу се сматрати семантичком основом у

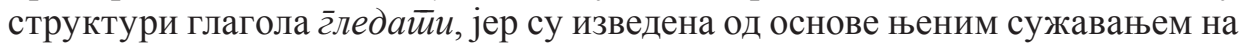
само једну значењску компоненту, која код 1.б. гласи имайи ойворене очи, а код 1.в. видейи (неког̄a), од којих су обе већ свакако укључене и подразумеване у оквиру основног значења.

Приликом одређивања примарног значења, у једнотомном речнику, унете су извесне измене:

гледати, -а̄м несвр. 1. а. ирримайи свейлосне уйиске чулом вида, ойажайи чулом вида: не моћи . б. уйрављайи иооглед (очи) у неком ирравиу; обухвайайи

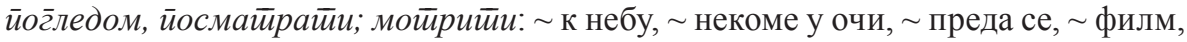

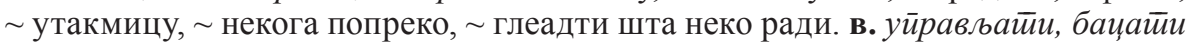

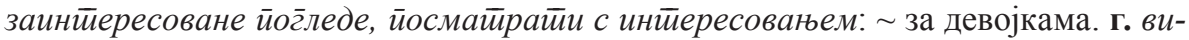

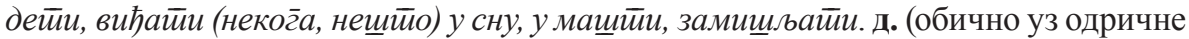
облике глагола моћи и често појачаном допуном „очима”) (не) йодносийи, (не) $\bar{u} p \bar{u} e \bar{u} u$.

Примарно значење, 1.а, поклапа се са прототипом у центру структуре глагола глледайи. Међутим, одељку примарног значења у датом речничком чланку додато је још неколико значења, док су 1.б. и 1.в. из шестотомног речника елиминисана ${ }^{2}$. Ипак, не може се тврдити да су сва додата значења с правом нашла место у оквиру примарног. Значења 1.б. и 1.в. су уско повезана са основним значењем јер су од њега изведена изменом једне компоненте (као код значења 1.а. у шестотомном речнику) или, пак, додавањем компоненте на одређени начин (заиниеересовано), те би као таква у значењској мрежи била позиционирана ближе прототипу, што није случај са значењима 1.г. и 1.д. која су изведена од основног деловањем механизма метафоричког преноса, где се визуелна перцепција повезује са когницијом, и то по обраСЦУ ГЛЕДАТИ ЗНАЧИ ЗАМИШЉАТИ (1.Г) И ГЛЕДАТИ НЕКОГА ЗНАЧИ ИМАТИ ОДРЕЪЕНО МИШљЕњЕ О њЕМУ/њОј (1.Д). С обзиром на начин извођења, ова значења су у семантичкој мрежи удаљенија од прототипа у односу на претходно поменута, те се не могу груписати заједно са прототипским у оквиру примарног одељка у речничком чланку, већ би их требало означити као секундарна значења.

У погледу селекције значења уврштених у речнички чланак, приметна је чињеница да је одељак примарног значења у једнотомном речнику богатији по броју подзначења у односу на шестотомни. Међутим, дати речнички одељак обогаћен је махом фигуративним значењима, чиме се значењска структу-

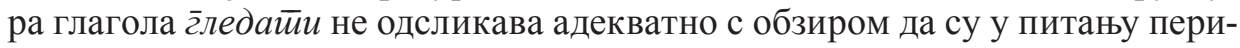
ферна значења. Ипак, предност лексикографског поступка у једнотомном

\footnotetext{
Овде се претпоставља да је значење 1.б. изостављено јер је већ подразумевано и обухваћено основ-
} ним значењем, док је значење 1.в. изостављено као застарело у савременом српском језику. 
речнику огледа се у идентификацији основног значења у складу са прототипом семантичке структуре посматраног глагола.

\subsection{2 Диференцијација секундарних значења}

Диференцијација секундарних значења извршена је на основу неколико различитих критеријума у оба посматрана речника, који се могу сумирати на следећи начин:

1. граматичке одлике;

2. метафорички трансфер значења;

3. специфичност референта;

4. варијација значењске компоненте;

5. устаљеност израза.

У шестотомном речнику одмах иза примарног значења следи одељак са два значења установљена на основу метафоричког преноса значења:

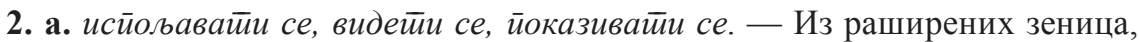

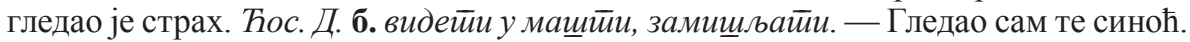
Црну. Тужну. Мртву. Матиощи.

Међутим, значење 2.а. реализује се у врло специфичном контексту, те је дискутабилно да ли је фреквентност његовог јављања довољна да би се дата употреба идентификовала као засебно значење, док је значење 2.б. утврђено по истом основу као значење 1.г. у једнотомном речнику.

Следеће значење у оквиру посматраног речничког чланка шестотомни речник дели са једнотомним, а утврђено је на основу визуелне апроксимације:

3. бийи усмерен, окренуй (ирема некоме, нечему). — Топ гледа ... управо у нашу војску. Нен. М. Овећи прозор... гледа у мало двориште. Нех. фиг. Српски народ треба да гледа напред у будућност, а не натраг у средњи век. Скерл.

Ипак, с обзиром на своју позицију на листи значења у једнотомном речнику (2.), очигледно је да је ово значење схваћено ближе прототипском у поређењу са позицијом истог значења у шестотомном речнику.

Такође, потребно је истаћи и запажање да се у оквиру одељка значења 3. у шестотомном и 2. у једнотомном речнику јавља илустрација фигуративне употребе, која није изведена визуелном апроксимацијом као дефинисано значење у оквиру кога је илустрована, те би је требало третирати као посебно значење утврђено на основу деловања механизма метафоре по обрасцУ ГЛЕДАТИ ЈЕ РАЗмИШљАТИ, а Последично се као засебно значење мора и адекватно нумерисати у речничком чланку.

Препознавањем специфичног референта (карӣе, йлећка, щиљљица) установљено је значење 4. у шестотомном речнику, односно 3. у једнотомном речнику, али у оба случаја перцепирано је као значење ближе прототипском у поређењу са низом употреба изведених метафором, које следе у датом речничком чланку:

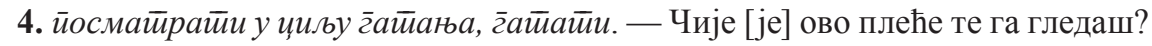
Њег̄ou. Госпођа Олга... гледа у кавену шалицу. Јел. 
Значења 5, 7, 8, 9 у шестотомном речнику идентификована су препознавањем неког од метафоричких образаца који повезују визуелну перцепцију са когницијом, емоционалношћу и, уопште, доменом људског ума:

5. битии наклоњен, волетии. - Мујо гледа у махали Ајку, Мујо гледа, а мајка му не да. НПХ. Јеси ли ти находио у вашим књигама... да дјевојка ваше вјере — гледа Турчина? Андр. И.

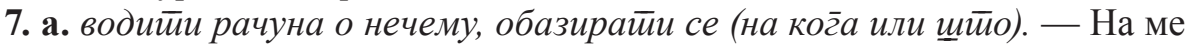
није ни гледао. Наз. На то што је некад било данас више нико не гледа. Ћос. Б.

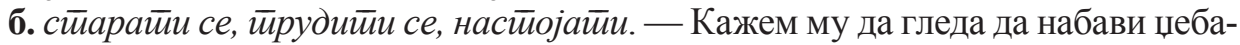
не. Нен. М. Гледај, па порани! Ад. Гледао је да не разговара ни с ким. Хорв. в.

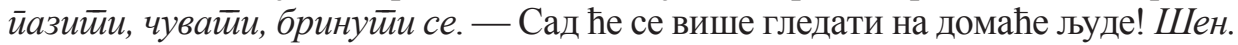
Да ли ће ми децу гледати? Вес. Гледајте ми најприје вечеру. Јурк. Деда гледа

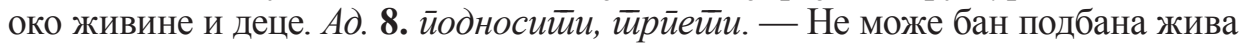
гледати. Шен. Пази госпочиће ... Е, баш не могу да их гледам. Срем. 9. одно-

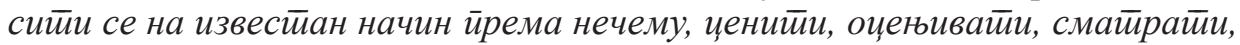
налазийи. - Омладина почиње стварније да гледа на ствари целога племена. $J o в . J$. У доброчинству гледа средство које... срце и душу весели. Скерл.

Тако, значење 5. дефинисано је на основу обрасца глЕдАТИ знАчи волЕТи, 7. ГЛЕДАТИ ЗНАЧИ БРИНУТИ СЕ/ТРУДИТИ СЕ ОКО НЕКОГА/НЕЧЕГА, 8. ГЛЕДАТИ НЕКОГА ЗНАЧИ МОЋИ ТРПЕТИ ФЕГА/њУ, 9. ГЛЕДАТИ НЕШТО ЗНАЧИ ИМАТИ СТАВ ПРЕМА ТОМЕ. Потребно је напоменути да је критеријум за идентификацију значења 7.а. и 7.в. заправо двојак, јер поред метафоре укључује и специфичну синтаксичку структуру у којој се ово значење јавља (гледати+на кога/што).

Сва наведена значења изузев значења 5. које се , како се овде претпоставља, сматра застарелим, јављају се и у једнотомном речнику, али су другачије нумерисана, што истовремено сведочи и о томе да се у двама речницима различито перцепира њихова удаљеност од прототипа. Тако, значење 7.a. је у једнотомном речнику обележено ознаком 6, 7.б. истом ознаком, 7.в. ознаком 7.a, 8. ознаком 1.д, 9. ознаком 4.а.

4. а. односитии се на одређен начин ирема некоме, нечему, имайи одређен

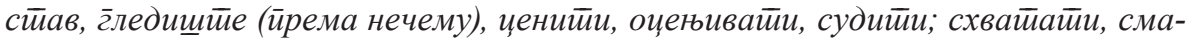
$\bar{u} р а \bar{u} u$, држайи: $\sim$ рално на догађаје, $\sim$ различито (на) ствари; оптимистички, зависно од тога како се гледа, (некога) као лирског песника.

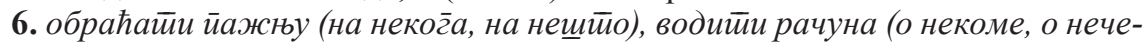
мy), обазирайи се (на неког̄a, на нещйо): не на некога, на године, $\sim$ на нечије

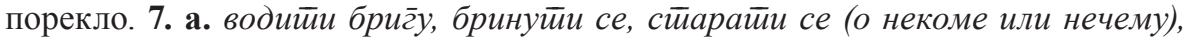

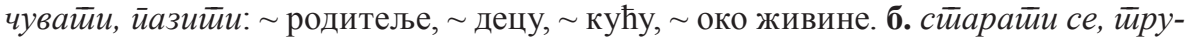
дийи се, настиојайи

Употреба глагола глледайи која захтева специфичан референт (девојку) није присутна у једнотомном речнику, али је у шестотомном позиционирана као значење 6:

6. уйознавайи (девојку). — Идеш да гледаш девојку. Иг̄ґ. 
С друге стране, у једнотомном речнику, иако је мањег обима, дефинисане су извесне употребе глагола г̇ледай $u$ које се не јављају у шестотомном речнику, попут значења 5.а. установљеног захваљујући присуству додатне значењске компоненте (с одређеним циљем/намером), те 5.б. препознатог захваљујући специфичној синтаксичкој карактеристици - јављању само у 2. лицу императива. Додата су и значења 8.а, 8.6 и 9, сва установљена на основу метафоричког проширења значења, док се значење 10. препознаје по назначеној специфичној граматичкој употреби.

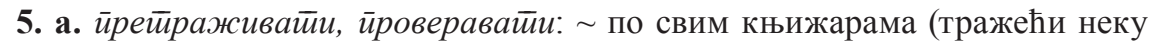
књигу). б. (у 2. л. имп. ) види, уйореди, йровери. - Гледај 22. стих.

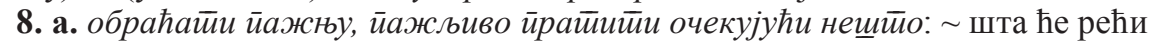
вођа. б. йолаг̄айи наду у неког̄a: у вођу (као у Бога), на некога као на спасиоца.

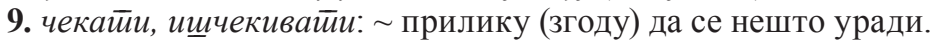

У погледу опште стратегије диференцијације значења, а на основу представљене анализе, закључује се да се у оба речника задржава тежња ка груписању значења која се перцепирају као сродна или се, пак, више употреба слива у једну. Ова стратегија свакако омогућава јаснији увид у међусобне деривационе односе периферних значења у смислу њихове међусобне блискости на основу начина извођења, као и њиховог односа према прототипу. Међутим, у неким случајевима, груписање појединих значења у исти нумерисани одељак није оправдано, јер су настала деловањем два потпуно различита механизма, те и суштински представљају две различите употребе, које је потребно означити као засебне (нпр. значењски одељак 1. у једнотомном речнику, 2. у једнотомном речнику).

\section{2. Структура и организација речничког чланка}

\subsection{1 Структура}

Приметно је да се у шестотомном, као и једнотомном речнику, тежи хијерархијској структури речничког чланка, што је и очекивано с обзиром на уочену општу стратегију груписања неколико значења у оквиру истог нумерисаног одељка. Хијерархијска устројеност подразумева најпре груписање значења која деле исту главну или доминантну семантичку компоненту у један одељак у оквиру речничког чланка. Најопштије значење се издваја као надређено и у складу са тим и позиционира као прво у одељку, док се ужа и специфичнија значења излиставају после надређеног значења у виду његових подзначења, те се као таква и обележавају.

Принцип хијерархијске структуре је само делимично реализован у оба речника. Непотпуна усклађеност са датим принципом односи се на критеријум примењен приликом груписања значења, који није у свим случајевима јасно одређен, а самим тим и лако препознатљив корисницима речника. Пример оваквог груписања јесте одељак примарног значења у једнотомном речнику, који, поред употреба 1.a, б, в. које повезује заједничка доминантна значењска компонента визуелне перцепције, обухвата и две фигуративне 
употребе, 1.г, д, које припадају периферним значењима, тј. изведена метафором бивају удаљеније позиционирана у односу на прототипско значење. Значење број 2. у шестотомном речнику, такође, представља одељак са две употребе које су груписане као значења изведена путем истог механизма, метафоре. Међутим, она не деле исти метафорички образац, те су им самим тим и централне компоненте значења различите.

Ипак, пример груписања значења која деле доминантну значењску компоненту јесте значење 7. како у једнотомном, тако и у вишетомном речнику. Сва груписана значења заснована су на метафоричком преносу.

\subsection{2 Организација}

Поред начина груписања значења, други проблематичан аспект је и организација сваког нумерисаног одељка у оквиру речничког чланка. Наиме, у оквиру група значења не постоји надређено значење које ће својом општом дефиницијом обухватити доминантну компоненту значења свих излистаних подзначења, чиме би се главна значења лексеме јасно истакла, што би свакако допринело и прегледности чланка, а и деривациони пут подзначења би био лако уочљив.

Неизоставан аспект организације речничког чланка јесте и утврђивање редоследа значења узевши у обзир њихов међусобни однос, али и однос сваког од њих према прототипском значењу. Логичан редослед значења у складу са когнитивним приступом полисемији и теоријом прототипа јесте од центра ка периферији, према коме се прототипско значење означава као прво у листи значења а прате га периферна значења, која се даље ређају према опадајућој скали њихове удаљености од прототипа у значењској мрежи или, пак, према својој фреквентности у језичкој употреби. Значења која деле прототипску значењску компоненту визуелне перцепције груписана су и означена као прва у оквиру чланка у оба речника. Затим следе периферна значења, али правило „од центра ка периферији” је тиме само делимично испоштовано, јер периферна значења нису систематично поређана по опадајућој скали своје удаљености од прототипа, што је случај у оба речника. Тако, у шестотомном речнику значење 3. изведено визуелном апроксимацијом постављено је иза фигуративног значења 2. иако је прво поменуто значење ближе прототипу у значењској мрежи. Потом се нижу пренесена значења, међу којима и значење 6 , које се овде сматра застарелим или ретко употребљаваним у савременом српском језику, те би као такво, следећи логички редослед, требало бити позиционирано иза осталих пренесених значења, 7,8,9, која су фреквентнија у језичкој употреби.

У једнотомном речнику, редослед периферних значења такође не следи опадајућу скалу блискости са прототипом. Значење 5 , које је директно изведено од прототипа додавањем само једне значењске компоненте, позиционирано је иза пренесених значења 3,4 . Сличан случај је и са значењем 10. које је излистано као последње у чланку иако је сасвим блиско прототипу. 


\section{3. Илустрација контекста}

Илустрација контекста неопходна је као потпора речничким дефиницијама ради јаснијег представљања значења, али и типичних структура у којима се јављају. Када је реч о овом аспекту лексикографске праксе, постоје значајне разлике између два анализирана речника.

У оба речника употребљена су различита средства за илустрацију типичног контекста у којем се одређено значење јавља. У шестотомном речнику, ипак, доминира средство које подразумевање преузимање реченице из неког од истакнутих српских књижевних дела. Употреба читаве реченице је сасвим одговарајућа у смислу представљања целовите структуре у којој се реч јавља. Међутим, многе од употребљених реченица нису уобичајене за савремену употребу српског језика, те се поставља питање њихове илустративности у смислу разјашњавања дефиниције значења и међусобног разликовања сродних значења. Примери оваквих реченица присутни су у илустрацији значења 4 :

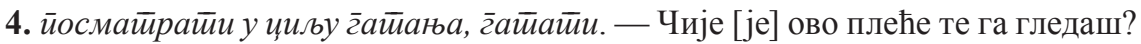
Њег̄ou. Госпођа Олга .... гледа у кавену шалицу. Јел.

Неке од употребљених реченица нису адекватно одабране као средство илустрације типичног контекста, јер не одражавају специфичност посматраног значења на основу које се оно јасно диференцира од осталих употреба глагола г̄ледайи. Такав случај присутан је у илустрацији следећег значења:

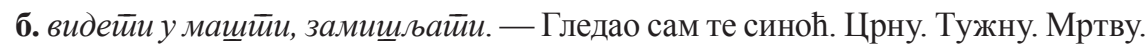
Мā̄oü.

Употребљена реченица требало би да илуструје пренесено значење, али понуђени контекст не диференцира јасно дату метафоричку употребу од примарне употребе глагола глледайи, која се односи на чин посматрања.

Уз реченице, као илустрација контекста, уочена је и употреба антонима код значења 1.б, што је оправдано, иако је илустрација постигнута само једном речју, јер сасвим недвосмислено разјашњава контекст у коме се дато значење може јавити:

1. б. имайи ойворене очи; супр. жмурити.

С друге стране, у једнотомном речнику, реченица као илустрација контекста јавља се код свега четири подзначења, и то, за разлику од шестотомног речника, ове реченице нису преузете из књижевних дела, већ корпуса свакодневне савремене употребе језика, чиме се постиже висок ниво илустративности:

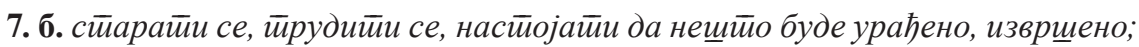

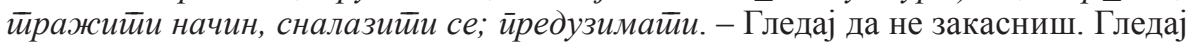
нешто за ручак.

Контекст који се нуди код осталих значења су фразе, које представљају типичне конструкције у којима се глагол глледайи јавља у одређеном значењу укључујући и типичне објекте и прилоге, као у примерима: 


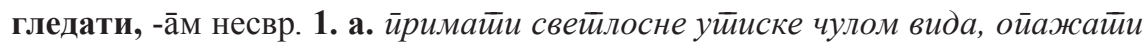

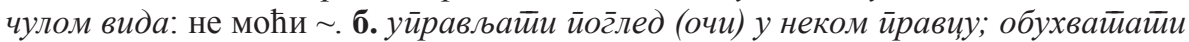

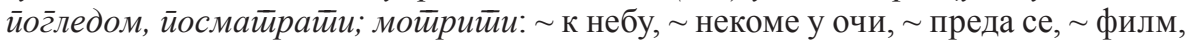
утакмицу, некога попреко, глеадти шта неко ради.

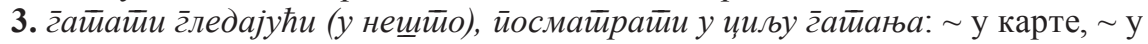
шољицу кафе, у плећку.

Иако су у питању само фразе, а не целовите реченице, контекст је сасвим јасно и прецизно илустрован захваљујући упућивању на типичне референте са којима се глагол глледай и јавља у датом значењу. Код значења која су препозната захваљујући специфичној синтаксичкој конструкцији у којој се јављају, уз илустрацију реченицом у загради је додато и граматичко објашњење:

10. (у 2. л. имп. ) за истиицање исказа: г̄ле, етио, йази. - Гледај ти ње! Гледај ти за кога се она распитује.

\section{5. ЗАКЉУЧАК}

Представљена анализа показала је да постоје извесне разлике између два посматрана речника у погледу стратегија које су у њима примењене при обради вишезначних лексема, и то узимајући у обзир сва три испитивана аспекта.

Стратегије идентификовања и диференцирања значења унапређене су у једнотомном речнику, пре свега у смислу усклађености лексикографске праксе са достигнућима лексиколошке теорије, у овом случају, теорије прототипа. На ову тврдњу јасно указује идентификација примарног значења, које је истовремено и прототипско значење у полисемантичкој мрежи посматраног глагола глледайu, што није случај у вишетомном речнику. Такође, у листу значења једнотомног речника нису укључена застарела значења, која се готово и не јављају у употреби савременог српског језика. Истовремено, листа је и обогаћена значењима, која су присутна у савременој употреби, што може посведочити и о препознавању тананијих значењских нијанси и њиховом представљању у једнотомном речнику, нарочито у погледу пренесених значења.

Ипак, констатовано је и да се оба речника ослањају на исте критеријуме при диференцијацији значења, те да примењују и исту општу стратегију груписања значења, које за собом повлачи и тенденцију ка хијерархијском устројству речничког чланка. Ипак, иако поменута тенденција постоји у оба речника, ни у једном од њих, принципи хијерархијске структуре нису у потпуности испоштовани. Узрок томе је на првом месту непостојање издвојеног надређеног значења дефинисаног тако да обухвата суштинску значењску компоненту свих његових груписаних подзначења. Други разлог лежи у случајевима одсуства јасно дефинисаног критеријума за груписање значења у смислу повезивања значења која нису изведена од истог надређеног значења, што је нарочито уочљиво у једнотомном речнику у којем се 
значења блиска прототипу групишу заједно са значењима са периферних делова дате значењске мреже.

Редослед значења као важан аспект организације речничког чланка недоследно прати правило поретка „од центра (прототипа) ка периферији”, које налаже лексиколошко теоријско утемељење, тј. постулати теорије прототипа. То доказује чињеница да су, у оба посматрана речника, нека од периферних значења нашла своје место испред значења ближих прототипу у посматраној значењској структури.

У погледу илустрације типичног контекста у коме се одређено значење јавља, на основу извршене анализе, закључено је да је учињен корак напред у млађем једнотомном речнику, јер су илустративне реченице осавремењене и тиме учињене уобичајеним за савремену језичку употребу, а неретко и замењене илустративним фразама са типичним референтима (субјектом/ објектом) употпуњеним у неким случајевима граматичким објашњењима, чиме се постиже адекватна допуна речничке дефиниције у циљу потпуне представе одређеног значења и његовог јасног диференцирања у односу на остала значења у речничком чланку.

Предложене стратегије за унапређење уочених недостатака у лексикографској пракси два посматрана речника, тј. аспеката неутемељених у лексиколошкој теорији подразумевају јасно истицање прототипског значења, идентификацију и диференцијацију значења у складу са савременом језичком употребом, груписање значења на основу заједничког надређеног значења и њихово хијерархијско устројство, доследан редослед значења по правилу „од центра ка периферији” значењске мреже и адекватна илустрација типичног контекста, којом се постиже јасно разликовање појединачног значења од осталих употреба дате лексеме. Примена сугерисаних стратегија илустрована је делом предложеног речничког чланка:

гледати, -а̄м несврш. 1. примати светлосне утиске чулом вида, опажати чулом вида: не моћи . 1.a. имати отворене очи: супр. жмурийи, 1.б. управљати поглед (очи) у неком правцу; обухватати погледом; посматрати; мотрити: $\sim \kappa$ небу, $\sim$ некоме у очи, йреда се, филм, уйакмииу, неког̄а йойреко, гіледайи ийа неко padu. 1.в. управљати, бацати заинтересоване погледе, посматрати с интересовањем: за девојкама. 2. претраживати, проверавати: ио свим књижарама (тражећи неку књигу). 2.a. (у 2. л. имп.) види, упореди, провери: - Гледај 22. стиих. 3. (у 2. л. имп.) за истицање исказа: гле, ето, пази. - Гледај йи ње! Гледај йи за ког̄a се она расиийије. 4. бити усмерен, окренут (према нечему). - Прозор глледа на улииу. 5. гатати гледајући (у нешто), посматрати у циљу гатања: $\sim$ у карие,$\sim y \underline{m о љ и и у ~}$ кафе, $\sim$ йлећку. 6. видети, вићати (некога, нешто) у сну, у машти, замишљати: Кад зажмурим глледам је како йлеще йо жиии. 7. размишљати о будућности: найред у будућности. 8. односити се на одређен начин према некоме, нечему. 8.a. имати одређен став, гледиште (према нечему), ценити, оцењивати, судити; схватати, сматрати, држати: реално на дог̄ађаје, различийо (на) стиввари, оййимисииччки. 8.б. (у некоме, нечему) налазити, видети, сматрати: у некоме нейрија$\bar{u} е љ a$. 8.в. (обично уз одричне облике глагола моћи и често појачано допуном „очима”) (не) подносити, (не) трети: - Не могуу да га г ледам вище очима. 


\section{ЛИТЕРАТУРА}

Драгићевић, Р. (2007). Лексикологија српског језика. Београд: Завод за уџбенике. Гортан-Премк, Д. (2004). Полисемија и организација лексичког система у српскоме језику. Београд: Завод за уџбенике и наставна средства.

$$
* \quad * \quad *
$$

Cruse, A. (2004). Meaning in Language. Oxford: OUP.

Evans, V., \& Green, M. (2006). Cognitive Linguistics. An Introduction. Edinburgh: Edinburgh University Press.

Geeraerts, D. (1989). Prospects and Problems of Prototype Theory. Linguistics. 27: 587-612. Kilgarriff, A. (2006). Word Senses. In: Eneko, A., \& Edmonds, P. G. (Eds.). (2006). Word Sense Disambiguation: Algorithms and Applications. (pp. 29-45). New York: Springer.

Lewandowska-Tomaszczyk, B. (2007). Polysemy, Prototypes, and Radial Categories. In: Geeraerts, D., \& Cuyckens, H. (Eds.). (2007). The Oxford Handbook of Cognitive Linguistics (pp. 139-169). Oxford: Oxford University Press.

Zgusta, L. (1971). Manual of Lexicography. Prague: Academia Publishing House of the Czechoslovak Academy of Sciences.

\section{ИЗВОР}

Речник МС. Речник српскохрватскога књижевног језика. I. (1967). Нови Сад - Загреб: Матица српска - Матица хрватска.

Речник МС. Речник српскога језика. (2007). Нови Сад: Матица српска.

Ана Халас

\section{ОБРАДА ПОЛИСЕМИЈЕ У ШЕСТОТОМНОМ И ЈЕДНОТОМНОМ РЕЧНИКУ МАТИЦЕ СРПСКЕ}

\section{РЕЗИМЕ}

У овом раду анализиран је систем обраде вишезначних лексема у шестотомном и једнотомном Речнику Матице српске кроз три аспекта лексикографске праксе: идентификацију и диференцијацију значења, структуру и организацију речничког чланка и илустрацију типичног контекста у којем се дата лексема јавља у одређеном значењу. Анализа је извршена на примеру богате полисемантичке структуре глагола глледайи, која се одликује не само значајним бројем значења и подзначења, већ и разноврсношћу механизама укључених у деривацију ове значењске мреже. Поред идентификације карактеристика система обраде полисемије у сваком од посматраних речника у циљу утврђивања предности и недостатака, анализа је обухватила и поређење два система како би се стекао увид у правац развоја српске лексикографске праксе од старијег шестотомног до млађег једнотомног издања речника. Резултати испитивања указују на то да је стратегија идентификације и диференцијације значења унапређена у једнотомном речнику у односу на шестотомни захваљујући већем степену усклађености са лексиколошком теоријом прототипа у смислу идентификације прототипског, тј. примарног значења, као и захваљујући већем степену усклађености са 
савременом језичком употребом. У погледу структуре и организације речничког чланка, оба речника показују само тенденцију ка груписању значења и успостављању хијерархијске структуре, али њени принципи нису у потпуности реализовани услед непостојања јасно издвојеног надређеног значења у оквиру једне значењске групе, нејасно дефинисаних критеријума за само груписање значења, као и одступања од правила редоследа значења по принципу „од центра ка периферији” значењске мреже. Аспект илустрације типичног контекста унапређен је у једнотомном речнику захваљујући употреби реченичног контекста из корпуса савремене употребе српског језика и фраза са истакнутим типичним референтима, које доприносе прецизнијој диференцијацији одређеног значења у односу на суседна у посматраној значењској структури. Уочене предности и недостаци пружиле су смернице ка формирању речничког чланка у складу са достигнућима лексиколошке теорије и захтевима лексикографске праксе у погледу прегледног, јасног и прецизног представљања вишезначних лексема.

Ana Halas

\title{
TREATMENT OF POLYSEMY OF THE VERB GLEDATI (LOOK) IN SIX-VOLUME AND ONE-VOLUME DICTIONARY OF MATICA SRPSKA
}

\begin{abstract}
SUMMARY
This paper presents an analysis of the system applied in the treatment of polysemous lexemes in the six-volume and one-volume Dictionary of Matica srpska taking into account three aspects of lexicographical practice: sense discrimination, structure and organization of a dictionary entry and illustration of the context in which the given sense of a lexeme typically occurs. The analysis has included the rich polysemous structure of the verb gledati (look) that is characterized not only by a considerable number of senses and subsenses, but also by various mechanisms employed in the derivation of this semantic network. In addition to identifying the characteristics of the system applied in the treatment of polysemy in each of the examined dictionaries in order to determine its advantages and disadvantages, the analysis has also included the comparison of the two systems with the aim of gaining an insight into the direction in the development of Serbian lexicography from the older six-volume to the more modern one-volume edition of the dictionary. The analysis results have shown that the sense discrimination strategy has been improved in the one-volume dictionary in comparison to the six-volume dictionary due to its greater reliance on lexicological prototype theory in the sense of identifying the prototypical, i.e. primary sense as well as due to its greater reliance on the contemporary language use. As for the structure and organization of the dictionary entry, both dictionaries display only a tendency towards grouping of senses and their hierarchical structuring, but these principles have not been completely realized because of a lack of a clearly highlighted superordinate sense within a sense group, a lack of clearly defined criteria for sense grouping and the deviation from the sense ordering principle "from the center to the periphery" of the given sense network. The illustration of the typical context has been improved in the one-volume dictionary due to the use of a sentential context taken from the corpus of the contemporary language use and phrases with highlighted typical referents that contribute to the more precise differentiation of a particular sense in relation to the other senses in the examined semantic structure. The noticed advantages and disadvantages have indicated the direction towards forming a dictionary entry in accordance with the achievements in lexicological theory and requirements of lexicographical practice in the sense of neat, clear and precise presentation of polysemous lexemes.
\end{abstract}

Key words: lexicology, lexicography, prototype, polysemy 